misstates certain facts which I can not pass over in silence, lest this be interpreted as assent. He states, first, that we used " mongrel stock." "Therefore, any evidence furnished by the character of the offspring would be of doubtful value." On what Guthrie bases this statement I am unable to discover. It is wholly contrary to fact. We described in the body of our paper "one successful case" and in a postscript a second case complete except as regards the autopsy. In describing the successful case, p. 8 , the statement is expressly made that the ovary was taken from "a pure black guineapig." This guinea-pig belonged to a family of coal-black animals which I have had for about seven years. This family is descended without admixture of other blood from three original individuals, a male and two females, all intensely black, the progeny of which have been closely inbred now for several generations without ever producing any observable deviation from the solid black type of the progenitors. The albino grafted was also of pure race, one which I have bred for about ten years. The albino male with which the grafted animal was mated was of a different strain, but of known and tested gametic composition, so that I can state with much positiveness the kind of young which he produced (and would regularly produce) in matings with guinea-pigs of different color varieties.

The second successful case, described in a postscript, concerned a color variety which I originated, the brown-eyed cream, and which breeds very true, since all the color factors which it contains save one are recessive in nature. This variety can produce only one variety of colored young. It is the ultimate recessive colored variety of guinea-pig. Having originated this variety some years ago and bred it pure and in crosses ever since, I think I may justly claim to know something about its behavior in inheritance. In neither of the cases which we have described as "successful" was an animal used whose breeding capacity was not definitely and fully known, as definitely as we know what will happen when oxygen and hydrogen are combined.
The charge of "mongrel stock" is therefore groundless.

Guthrie's second criticism of our evidence is this, "It is not proved that the offspring may not have come from ovarian tissue of the host left in site after operation." But both the grafted animals were albinos and they were mated only with albino males. In all recorded cases, of which I have myself observed many hundred, albinos so mated produce only albino young. Had ovarian tissue been left in site after operation and liberated ova which developed, these should have produced albino young. But these grafted albinos, which had received an ovary from a colored animal, produced colored young, in each case of the particular color type that characterized the animal furnishing the graft. Is there really then any uncertainty about the source from which the functioning ova came?

$$
\begin{gathered}
\text { LABORATORY OF GENETICS, } \\
\text { BUSSEY INSTITUTION, } \\
\text { HARVARD UNIVERSITY, } \\
\text { June 21, } 1911
\end{gathered}
$$

W. E. Castle

\section{MEASURING THE MERIT OF ENGLISH WRITING}

To the Editor of Science: Professor Thorndike's article in ScIEnce of June 18 on a scale for measuring the merit of English writing, seems to parallel the old question: "Which is best, a pair of scissors or a pair of tongs?"

To have any value as a test of merit the writing of "pupils in their teens" should be comparative, and you can not properly compare paragraphs based on different topics, recollections or quotations from school readers, and attempts at expression of totally distinct emotions.

One method which might approximate to a basis of comparison would be to require from all the pupils a paraphrase of one single paragraph, as far as possible to be expressed in entirely different words from the original. Even this would be subject to the objection that a child writes best when it writes of something it naturally appreciates, and in which its interest is not forced; and the same 
bit of writing would rarely appeal to any large number of children in an equal degree or in the same way; consequently their relation to it would not be of a strictly comparative kind in a literary sense.

The examples given seem to me absolutely valueless for comparison. Number 607 is the production of an idiot. Number 520 is a quotation; no child in its teens could have conceived it. Number 434, if a genuine original, is the only one showing anything but a lesson poorly remembered, it is the only one not quoted or paraphrased from an adult production which has any literary merit at all. Wm. H. DaLL

\section{SMITHSONIAN INSTITUTION, June 19, 1911}

\section{GENOTYPES ARE THE SPECIES UPON WHICH GENERA ARE BASED}

The case presented by Dr. Stiles on page 620 of ScIENCE for April 21 last, possesses exceptional importance for the student of muscoid flies. Probably in no other superfamily of animals have as many misidentifications been made as in the Muscoidea. Species have been repeatedly confused, combined, jumbled and wrongly determined ever since the time of Meigen, if not before, until the tangle has now become frightfully intricate in character. Especially within the past decade or two have misidentifications of North American forms enormously increased, so that the literature is now overburdened with the resulting error, from which it will be a labor of great magnitude to free it.

The principle involved in misidentifications or cases of mistaken identity is always the same for all cases, and the problem is capable of only one correct solution. Of two diametrically opposed propositions, one must necessarily be right and the other wrong. While I can see the case clearly from both points of view, the wrong premises of the one view stand forth distinctly in my mind, and I can not grant that there exists here any necessity for arbitrary decision. The whole matter rests, of course, upon the adoption of rational and correct premises.
Properly approaching the question, its solution is simple, and I need only repeat here the axiomatic title at the head of these remarks.

The correct and only logical premises are represented in the axiom that EVERY RECORD OF A SPECIES OR OTHER TAXONOMIC UNIT IN THE LITERATURE BECOMES AT ONCE A PART OF THE SYNONYMY OF THE SPECIES OR. UNIT INTENDED FOR RECORD BY THE RECORDER. It makes no difference under what name the record be made, the entity referred to remains the same, and the synonymy of that entity is thereby enriched by the name used followed by the name of the author making the record together with the date of same. This precludes confusion whether or not misidentification exists. The genus $X$-us Jones, 1900, unmistakably has for its type, under the conditions of the problem as stated, the species albus Jones, 1900. The genotype can be no other than this, which is the particular form so identified by Jones at the time and by him intended as the type of his genus. Jones has. misidentified his genotype with Smith's species, hence the name albus Jones, 1900 (non Smith, 1890), becomes a synonym of the name that shall finally hold for the genotype, that is to say, the particular form indicated by Jones. It is conceivable that Jones might differently identify the same form at different times, hence the necessity for a synonym to take the date of publication, which should include the month and day if Jones is a voluminous and frequent publisher.

The fallacy of the opposite premises is very evident. Were we to admit the latter it would be impossible to present a rational synonymy of forms. In the above case, albus Smith, 1890, has no further connection with the matter in hand after it has been proved that albus Jones, 1900, is a different form. It should be evident that an author's record of a form must remain always a record of that form in his sense at the time of record. The name he uses is merely a handle by which we can ourselves find and locate that form. If we ever decide that a record of a form is not a record of the form in the sense 